\title{
A new proposal of the classification of irrigation water ${ }^{1}$
}

\author{
Uma nova proposta de classificação da água para fins de irrigação
}

\author{
Ana Célia Maia Meireles ${ }^{2 *}$, Eunice Maia de Andrade ${ }^{3}$, Luiz Carlos Guerreiro Chaves ${ }^{4}$, Horst Frischkorn ${ }^{5}$ e \\ Lindbergue Araujo Crisostomo ${ }^{6}$
}

\begin{abstract}
A study on surface water quality in the Acaraú Basin, in the North of the state of Ceará, Brazil was performed. Qualitative dynamics of water flowing to the Acaraú River that supplies water to the irrigation project in the area was evaluated. Multivariate Factor Analysis/Principal Component Analysis was used for evaluation of water quality in order to develop a water quality index (WQI) that reflects soil salinity and sodicity risks and water toxicity to plants. From April/2003 to September/2005 water were sampled from ten sampling sites covering the basin, where physical and chemical parameters that contribute to the WQI were evaluated. The results showed that the use of water for irrigation in the Acaraú basin, according to the proposed WQI, are potentially prone to cause toxicity (crop cycle) and sodicity problem in the long run, if the soil-water-plant is not carefully monitored.
\end{abstract}

Key words - Water Irrigation. Soils-salinity. Soils-sodium content. Acaraú Basin (Brazil).

\begin{abstract}
Resumo - Um estudo foi realizado sobre a qualidade da água de superfície na Bacia do Acaraú, porção Norte do estado do Ceará, Brasil. Foram avaliados os parâmetros qualitativos da água do Rio Acaraú que abastece o projeto de irrigação nessa área. Análise da Componente Principal/Análise do Fator Multivariada foi usada na avaliação da qualidade da água a fim de desenvolver um índice de qualidade de água (IQA) que refletisse os riscos de salinidade e sodicidade do solo bem como a toxicidade por íons específicos às plantas. As amostras de água foram coletadas em dez locais cobrindo toda a bacia no período de abril/2003 e setembro/2005, em que os parâmetros físicos e químicos que contribuem para o IQA foram avaliados. Os resultados mostraram que a águas utilizadas para irrigação na bacia do Acaraú, de acordo com o IQA proposto, são potencialmente propensas a causar problemas de sodicidade e toxicidade ao longo do tempo, se a relação solo-água-planta não for rigorosamente manejada.
\end{abstract}

Palavras-chave - Água de Irrigação. Solos-salinidade. Solos-teor de sódio. Bacia do Acaraú (Brasil).

\footnotetext{
* Corresponding author

${ }^{1}$ Received 07/10/2009; accepted 28/06/2010

Part of the doctoral thesis of first author

${ }^{2}$ Departamento de Engenharia Agrícola, CCA/UFC, Caixa Postal 6.003, Fortaleza-CE, Brasil, ameireles2003@yahoo.com.br

${ }^{3}$ Departamento de Engenharia Agrícola, CCA/UFC, Fortaleza-CE, Brasil, eandrade@ufc.br

${ }^{4}$ Departamento de Engenharia Agrícola, CCA/UFC, Fortaleza-CE, Brasil, luizcarlosguerreiro@gmail.com

${ }_{5}^{5}$ Departamento de Engenharia Hidráulica e Ambiental, DEHA/UFC, Fortaleza-CE, Brasil, cariri@ufc.br

${ }^{6}$ Embrapa Agroindústria Tropical, Fortaleza-CE, Brasil, lindberg@cnpat.embrapa.br
} 


\section{Introduction}

In order to attend the expected increase in food production for an estimated population of 8.5 billion inhabitants in 2025, irrigation area in the world will be intensified, especially in arid and semiarid regions. However, in these regions, an estimated 10\% of irrigated soils are affected by irrigation induced problems (salinity, sodicity, and waterlogging) and new areas need to be converted to irrigation, intensifying the problem (GHEYI, 2000).

In the Brazilian semiarid region, rainfall is generally abundant when compared to other arid and semiarid regions of the planet. Nevertheless, due to high evaporation losses hydrologic efficiency of dams in the region is estimated to be $1 / 3$ of the storage volume. In addition to elevated evaporation rates that lead to cyclic salinization processes in the stored, insufficient quality protection measures in water management contribute to quality deterioration (FUNCEME, 2002).

Simple but objective and interpretable methods that use the peculiar characteristics of water resources are necessary to simplify the analysis of surface water quality in the monitoring task (BOLLMAN; MARQUES, 2000). Water quality indexes can inform possible alterations (degradation or recovery) of water resources in time and space (ANDRADE et al., 2005; MENDIGUCHIA et al., 2004; PESCE; WUNDERLIN, 2000; TOLEDO; NICOLLELA, 2002).

Indexes based on specialist opinion and based on statistical methods are cited in the literature (ALMEIDA; SCHWARZBOLD, 2003; OTT, 1978). All of them have some degree of subjectivity, because they depend on the choice of variables upon which the major indicators of water quality are built. Thus generalization is not acceptable due to special characteristics of each water system. However indexes based on statistical techniques favor the recognition of the most characteristic indicators of the water body under study, (HAASE et al., 1989).

Factorial analysis allows the reduction of a great number of data obtained upon monitoring and permits an interpretation of the various constituents separately (DILLON; GOLDSTEIN, 1984; HAIR JUNIOR et al., 2005), making it possible to find a better selection of the relevant parameters for water quality classification (SIMEONOV et al., 2003; WUNDERLIN et al., 2001).

Parameters for evaluation of possible precipitation of salts, induction to salinity and sodicity due to irrigation practices are used to classify water for irrigation. However, a classification of water quality that considers the interaction of both salinity and soil sodicity with the toxicity risk is not available.
The objective of this work is to develop an irrigation water quality index that expresses possible alterations in water quality for irrigation and therefore facilitates evaluation/mitigation of possible problems caused to irrigated soil and plants.

\section{Material and methods}

\section{Study area}

The study was carried out in the northern portion of the State of Ceará, Northeastern Brazil, and it comprises the Acaraú river basin $\left(2^{\circ} 49^{\prime} 42^{\prime \prime}\right.$ and $4^{\circ} 58^{\prime} 17^{\prime \prime} \mathrm{S}$ and $39^{\circ} 41^{\prime} 04^{\prime \prime}$ and $\left.40^{\circ} 40^{\prime} 19^{\prime \prime} \mathrm{W}\right)$. It's the second most important one in Ceará, and it has an area of $14,423 \mathrm{~km}^{2}$, straightening towards the coast, with its main river flowing along the $\mathrm{S} / \mathrm{N}$ axis of the basin. The climate in the upper part of the basin is classified as BSw'h' (according to Köppen classification) semiarid steppe, hot, with winter drought and summer-autumn rainy season and an average monthly temperature above $18{ }^{\circ} \mathrm{C}$. The lower part of the basin is classified as Aw' tropical, wet-dry savanna with an average monthly temperature higher than $18{ }^{\circ} \mathrm{C}$ and a distinct dry season during low sun winter and wet one during summer. Annual rainfall by the Acaraú basin for the 2003 to 2005 period was $971.3,965.6$ and $555.7 \mathrm{~mm}$, respectively. Rainfall has a monomodal distribution with $80 \%$ of total annual rainfall concentrated in the months of February to May. Potential evaporation, estimated through Class A tank is $1,914 \mathrm{~mm} \mathrm{ano}^{-1}$. Local terrain is mainly formed by crystalline rocks.

According the soils map of the State of Ceará (IPLANCE, 1997), six types are predominant in the Acaraú basin: Planosols, Luvisols, Leptosols, Acrisols, Fluvisols and Ferralsols. These soils were classified based on drainage capacity and infiltration problems due to water sodicity, as described by Andrade et al. (2006). The location of surface water monitoring sites of this paper and the infiltration risk are presented in Figure 1.

Water samples were collected monthly from April/2003 to December/2003 and bi-monthly from January/2004 to September/2005, on each sampling point georeferenced. A total of 190 samples were analyzed. Sampling was performed at the outlet of each reservoir, since the objective was to evaluate the water used for irrigation in the basin. Physical-chemical and chemical analyses were performed of the Water and Soils laboratory at EMBRAPA/Tropical Agriculture, using Richards methods (RICHARDS, 1954). Calcium and magnesium were measured through atomic absorption spectrometry; sodium and potassium by flame photometry; chlorine by the Mohs, 


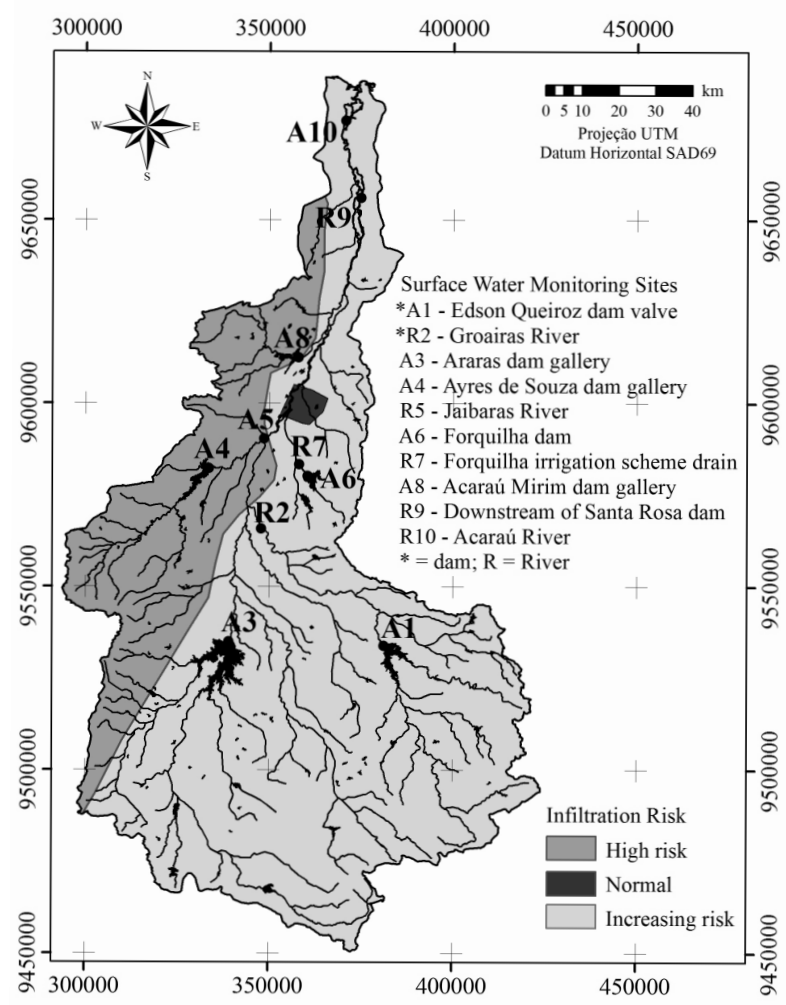

Figure 1 - Location of surface water monitoring sites and classification of infiltration risk with due to water sodicity in the Acaraú basin

method using silver nitrate as a titrating solution; sulfate by turbidimetry method, based on barium sulfate precipitation, using a spectrophotometer, as well as phosphate through molybdenum blue; bicarbonate, through titration with sulfuric acid, using methyl orange and phenolphthalein as indicator. Ammonia $\left(\mathrm{N}_{-} \mathrm{NH}_{4}^{+}\right)$and nitrate $\left(\mathrm{NO}_{3}^{-}\right)$were determined through double distillation in a micro-distillator with vapor drag. During the first distillation, calcinated magnesium oxide was used for ammonia estimate and during the second distillation a Devard's alloy was used for nitrate estimate. Distilled material was titration with sulfuric acid. Corrected Sodium Adsoption Ratio $\left(\mathrm{SAR}^{\circ}\right)$ was estimated according to Suarez (1981).

\section{Water quality index (WQI) development}

The water quality index (WQI) proposed in this study was developed in two steps. In the first step, parameters that contribute to most variability in irrigation water quality were identified using Principal Components and Factor Analysis (PC/FA) as described in SPSS (Statistical Package for the Social Sciences v.13). In the second step, a definition of quality measurement values $\left(\mathrm{q}_{\mathrm{i}}\right)$ and aggregation weights $\left(\mathrm{w}_{\mathrm{i}}\right)$ was established. Values of $\left(\mathrm{q}_{\mathrm{i}}\right)$ were estimated based on each parameter value, according to irrigation water quality parameters proposed by the University ofCaliforniaCommittee of Consultants - UCCC and by the criteria established by Ayers and Westcot (1999), shown in Table 1. Water quality parameters were represented by a non-dimensional number; the higher the value, the better the quality water.

Values of $\mathrm{q}_{\mathrm{i}}$ were calculated using the Equation 1, based on the tolerance limits shown in Table 1 and water quality results determined in laboratory:

$\left.\mathrm{q}_{\mathrm{i}}=\mathrm{q}_{\mathrm{imax}}-\left[\left(\mathrm{x}_{\mathrm{ij}}-\mathrm{x}_{\mathrm{inf}}\right) * \mathrm{q}_{\mathrm{iamp}}\right) / \mathrm{x}_{\text {amp }}\right]$

where $\mathrm{q}_{\text {imax }}$ is the maximum value of $\mathrm{q}_{\mathrm{i}}$ for the class; $x_{i j}$ is the observed value for the parameter; $x_{i n f}$ is the corresponding value to the lower limit of the class to which the parameter belongs; $\mathrm{q}_{\text {iamp }}$ is class amplitude; $\mathrm{x}_{\mathrm{amp}}$ is class amplitude to which the parameter belongs.

In order to evaluate $x_{a m p}$, of the last class of each parameter, the upper limit was considered to be the highest value determined in the physical-chemical and chemical analysis of the water samples.

Each parameter weight used in the WQI was obtained from the PC/FA, by the sum of all factors multiplied by the explainability of each parameter. Then $\mathrm{w}_{\mathrm{i}}$ values were normalized such that their sum equals one, according to Equation 2:

Table 1 - Parameter limiting values for quality measurement (qi) calculation

\begin{tabular}{|c|c|c|c|c|c|}
\hline \multirow{2}{*}{$\mathrm{q}_{\mathrm{i}}$} & \multirow{2}{*}{$\mathrm{EC}\left(\mathrm{dS} \mathrm{cm} \mathrm{cm}^{-1}\right)$} & \multirow{2}{*}{$\operatorname{SAR}^{\circ}\left(\operatorname{mmol}_{\mathrm{c}} \mathrm{L}^{-1}\right)^{1 / 2}$} & $\mathrm{Na}^{+}$ & $\mathrm{Cl}^{-}$ & $\mathrm{HCO}_{3}^{-}$ \\
\hline & & & \multicolumn{3}{|c|}{ 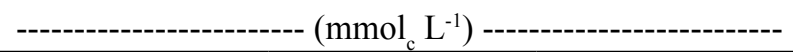 } \\
\hline $85-100$ & $0.20 \leq \mathrm{CE}<0.75$ & $2 \leq \mathrm{SAR}^{\circ}<3$ & $2 \leq \mathrm{Na}<3$ & $1 \leq \mathrm{Cl}<4$ & $1 \leq \mathrm{HCO}_{3}<1.5$ \\
\hline $60-85$ & $0.75 \leq \mathrm{CE}<1.50$ & $3 \leq \mathrm{SAR}^{\circ}<6$ & $3 \leq \mathrm{Na}<6$ & $4 \leq \mathrm{Cl}<7$ & $1.5 \leq \mathrm{HCO}_{3}<4.5$ \\
\hline $35-60$ & $1.50 \leq \mathrm{CE}<3.00$ & $6 \leq \mathrm{SAR}^{\circ}<12$ & $6 \leq \mathrm{Na}<9$ & $7 \leq \mathrm{Cl}<10$ & $4.5 \leq \mathrm{HCO}_{3}<8.5$ \\
\hline $0-35$ & $\mathrm{EC}<0.20$ or $\mathrm{EC} \geq 3.00$ & $\mathrm{SAR}^{\circ}<2$ or $\mathrm{SAR}^{\circ} \geq 12$ & $\mathrm{Na}<2$ or $\mathrm{Na} \geq 9$ & $\mathrm{Cl}<1$ or $\mathrm{Cl} \geq 10$ & $\begin{aligned} \mathrm{HCO}_{3} & <1 \text { or } \\
\mathrm{HCO}_{3} & \geq 8.5\end{aligned}$ \\
\hline
\end{tabular}


$w i=\sum_{j=1}^{k} F_{j} A_{i j} / \sum_{j=1}^{k} \sum_{i=1}^{n} F_{j} A_{i j}$

where $w_{\mathrm{i}}$ is the weight of the parameter for the WQI; $F=$ component 1 autovalue; $A_{\mathrm{ij}}$ is the explainability of parameter $\mathrm{i}$ by factor $\mathrm{j} ; i$ is the number of physicalchemical and chemical parameters selected by the model, ranging from 1 to $\mathrm{n} ; \mathrm{j}$ is the number of factors selected in the model, varying from 1 to $\mathrm{k}$.

The water quality index was calculated as:

$$
\mathrm{WQI}=\sum_{\mathrm{i}=1}^{\mathrm{n}} \mathrm{q}_{\mathrm{i}} \mathrm{w}_{\mathrm{i}}
$$

WQI is dimensionless parameter ranging from 0 to $100 ; q_{i}$ is the quality of the $\mathrm{i}^{\text {th }}$ parameter, a number from 0 to 100 , function of its concentration or measurement; $w_{\mathrm{i}}$ is the normalized weight of the $\mathrm{i}^{\text {th }}$ parameter, function of its importance in explaining the global variability in water quality.

The correlation matrix was calculated based on the normalized data of the 13 parameters studied, evaluated for the sampling sites throughout the basin. Based on correlation matrix. A preliminary analysis of the representative parameters of water quality was performed. According to Helena et al (2000) only values above 0.5 should be considered; this rationale was adopted used in the study.

In order to identify the most significant interrelation of water quality parameters in the Acaraú River, for each resulting factor of $\mathrm{PC}$, a matrix rotation procedure was adopted using the Varimax method. This method minimizes the contribution of parameters with a lower significance in the factor such that the parameters will present loads close to one or zero, eliminating the intermediate values, which difficult interpretation. A similar process was adopted by Vega et al. (1998), Helena et al. (2000) and Wunderlin et al. (2001) upon study of temporal variation of water quality, making interpretation of data easier.

\section{Results and discussion}

High correlations (above 0.9) were observed between $\mathrm{EC}$ and $\mathrm{HCO}_{3}^{-} ; \mathrm{Cl}^{-}$and $\mathrm{Na}^{+}$, and between $\mathrm{Na}^{+}$ and $\mathrm{SAR}^{\circ}$ (TAB. 2). These results seem to be connected to seasonal effects, as waters show higher concentration of bicarbonate during the rainy season and sodium and chloride enrichment in the dry season due to intense evaporation.

Kaiser-Meyer-Olkin (KMO) adequacy test for coefficient magnitude comparison indicated an optimum value of 0.82 , considered as indicating that the factorial model may be applied without restrictions. A similar result was found by Parinet et al. (2004) in an evaluation of water quality in tropical lake systems, with a KMO value of 0.85 , considered adequate for the study.

Application of Principal Component Analysis to describe dispersion of original parameters implied in a three component model, explaining $72.30 \%$ of total variance, diluted in thirteen dimensions. This result is in agreement with the works of Helena et al. (2000), Prado

Table 2 - Correlation matrix for the analyzed parameters

\begin{tabular}{|c|c|c|c|c|c|c|c|c|c|c|c|c|c|}
\hline & $\mathrm{EC}$ & $\mathrm{pH}$ & $\mathrm{Ca}^{2+}$ & $\mathrm{Mg}^{2+}$ & $\mathrm{Na}^{+}$ & $\mathrm{K}^{+}$ & $\mathrm{Cl}^{-}$ & $\mathrm{HCO}_{3}^{-}$ & $\mathrm{SO}_{4}^{2-}$ & $\mathrm{PO}_{4}^{3-}$ & $\mathrm{NH}_{4}^{+}$ & $\mathrm{NO}_{3}^{-}$ & SAR $^{\circ}$ \\
\hline $\mathrm{EC}$ & 1.00 & & & & & & & & & & & & \\
\hline $\mathrm{pH}$ & 0.47 & 1.00 & & & & & & & & & & & \\
\hline $\mathrm{Ca}^{2+}$ & 0.60 & 0.22 & 1.00 & & & & & & & & & & \\
\hline $\mathrm{Mg}^{2+}$ & 0.79 & 0.51 & 0.56 & 1.00 & & & & & & & & & \\
\hline $\mathrm{Na}^{+}$ & 0.91 & 0.40 & 0.53 & 0.69 & 1.00 & & & & & & & & \\
\hline $\mathrm{K}^{+}$ & 0.65 & 0.21 & 0.46 & 0.46 & 0.69 & 1.00 & & & & & & & \\
\hline $\mathrm{Cl}^{-}$ & 0.92 & 0.42 & 0.54 & 0.67 & 0.81 & 0.60 & 1.00 & & & & & & \\
\hline $\mathrm{HCO}_{3}^{-}$ & 0.95 & 0.43 & 0.59 & 0.79 & 0.89 & 0.66 & 0.81 & 1.00 & & & & & \\
\hline $\mathrm{SO}_{4}^{2-}$ & 0.07 & -0.20 & 0.00 & -0.08 & 0.04 & 0.09 & 0.08 & -0.04 & 1.00 & & & & \\
\hline $\mathrm{PO}_{4}^{3-}$ & 0.05 & -0.04 & 0.03 & 0.11 & 0.04 & 0.24 & 0.06 & 0.06 & -0.095 & 1.00 & & & \\
\hline $\mathrm{NH}_{4}^{+}$ & 0.21 & -0.09 & 0.14 & 0.13 & 0.21 & 0.49 & 0.24 & 0.23 & 0.48 & 0.52 & 1.00 & & \\
\hline $\mathrm{NO}_{3}^{-}$ & 0.15 & -0.08 & 0.10 & 0.13 & 0.11 & 0.15 & 0.11 & 0.21 & -0.17 & 0.34 & 0.31 & 1.00 & \\
\hline $\mathrm{SAR}^{\circ}$ & 0.83 & 0.37 & 0.497 & 0.53 & 0.94 & 0.65 & 0.75 & 0.80 & 0.06 & 0.35 & 0.15 & 0.31 & 1.00 \\
\hline
\end{tabular}


et al. (2002) and Simeonov et al. (2003) in which the two to three first generated components explain a great part of the variation of original data (60 to $90 \%$ ), in many cases, allowing the use of these components to describe the entire data system without significant loss of information.

Selection of this three component model used the criterion described by Norusis (1990) that is, considering only those components with a variance that has an auto-value above one, based on the fact that any component must explain a variance above that presented by a single variable.

This criterion is adopted by various authors and may be observed in works like that of Mendiguchia et al. (2004) upon evaluation of anthropogenic effects in water quality in the Guadalquivir river in the South of Spain, where through PC three hidrochemical factors were identified with variances above unity and explaining $79.1 \%$ of total variance of the data.

A matrix rotation was performed and data for factorial loads and communalities after transformation are presented in Table 3.

According to Table, the first Factor explains $48.37 \%$ of total variance in the data, whereas the second and third factor explains $14.21 \%$ and 9.72\%, respectively. In the first Factor/Component, parameters $\mathrm{EC}, \mathrm{Mg}^{2+}, \mathrm{Na}^{+}, \mathrm{K}^{+}, \mathrm{Cl}^{-}, \mathrm{HCO}_{3}{ }^{-}$and $\mathrm{SAR}^{\circ}$ present a load above 0.70 , indicating the most common composition of the observed parameters. These parameters are associated to water quality affected by mineralization processes (BRODNJAK-VONCINA et al., 2002).

In the second Factor/Component, parameters $\mathrm{PO}_{4}{ }^{3-}$, $\mathrm{NH}_{4}^{+}$and $\mathrm{NO}_{3}{ }^{-}$show highest factorial loads of $0.805,0.794$, and 0.661 , respectively, that may be associated to the presence of organic fertilizers used in agriculture within the basin. The third Factor/Component showed $\mathrm{SO}_{4}{ }^{2-}$ as the element with the highest load (0.859), suggesting the presence of chemical fertilizers (ELMI et al., 2004). According to Holanda and Amorim (1997), water in Northeastern Brazil is usually poor in sulfate. The second and third Factor represent surface flow with sediment load from agricultural areas, sewage and solid wastes inadequately disposed of close to water courses. According to the 2000 Census (IBGE, 2002), $40 \%$ of urban houses and $99 \%$ of rural houses burn, bury or dispose of garbage in unused open spaces, rivers, lakes, or other places where waste is not collected.

\section{WQI development}

In order to develop the proposed WQI, parameters $\mathrm{EC}, \mathrm{Na}^{+}, \mathrm{Cl}^{-}, \mathrm{HCO}_{3}^{-}$, and $\mathrm{SAR}^{\circ}$ were used. These carry the major factorial load, that is, define best water quality. Henceforth, the weight of each parameter was based on the variance of the first Factor (TAB. 1), associated to the

Table 3 - Factorial loads and communalities for the observed parameters

\begin{tabular}{|c|c|c|c|c|}
\hline \multirow{2}{*}{ Parameters } & \multicolumn{3}{|c|}{ Factorial loads matrix } & \multirow{2}{*}{ Communality } \\
\hline & $\mathrm{F} 1$ & $\mathrm{~F} 2$ & F3 & \\
\hline $\mathrm{EC}\left(\mathrm{dS} \mathrm{m} \mathrm{m}^{-1}\right)$ & 0.974 & 0.058 & -0.030 & 0.953 \\
\hline $\mathrm{pH}$ & 0.507 & -0.223 & -0.522 & 0.579 \\
\hline $\mathrm{Ca}^{2+}\left(\mathrm{mmol}_{\mathrm{c}} \mathrm{L}^{-1}\right)$ & 0.651 & 0.063 & -0.035 & 0.429 \\
\hline $\mathrm{Mg}^{2+}\left(\mathrm{mmol}_{\mathrm{c}} \mathrm{L}^{-1}\right)$ & 0.791 & 0.055 & -0.278 & 0.706 \\
\hline $\mathrm{Na}^{+}\left(\mathrm{mmol}_{\mathrm{c}} \mathrm{L}^{-1}\right)$ & 0.946 & 0.058 & 0.025 & 0.898 \\
\hline $\mathrm{K}^{+}\left(\mathrm{mmol}_{\mathrm{c}} \mathrm{L}^{-1}\right)$ & 0.715 & 0.373 & 0.228 & 0.702 \\
\hline $\mathrm{Cl}^{-}\left(\mathrm{mmol}_{\mathrm{c}} \mathrm{L}^{-1}\right)$ & 0.896 & 0.068 & 0.019 & 0.807 \\
\hline $\mathrm{HCO}_{3}^{-}\left(\mathrm{mmol}_{\mathrm{c}} \mathrm{L}^{-1}\right)$ & 0.936 & 0.114 & -0.110 & 0.901 \\
\hline $\mathrm{SO}_{4}^{2-}\left(\mathrm{mmol}_{\mathrm{c}} \mathrm{L}^{-1}\right)$ & 0.082 & -0.156 & 0.859 & 0.769 \\
\hline $\mathrm{PO}_{4}^{3-}\left(\mathrm{mmol}_{\mathrm{c}} \mathrm{L}^{-1}\right)$ & -0.001 & 0.805 & -0.058 & 0.651 \\
\hline $\mathrm{NH}_{4}^{+}\left(\mathrm{mg} \mathrm{L}^{-1}\right)$ & 0.190 & 0.794 & 0.247 & 0.727 \\
\hline $\mathrm{NO}_{3}^{-}\left(\mathrm{mg} \mathrm{L}^{-1}\right)$ & 0.069 & 0.661 & -0.250 & 0.504 \\
\hline $\mathrm{SAR}^{\circ}$ & 0.875 & 0.024 & 0.066 & 0.771 \\
\hline Variance & 6.287 & 1.848 & 1.263 & \\
\hline Variance $(\%)$ & 48.37 & 14.21 & 9.72 & \\
\hline
\end{tabular}

* 1 mmolc L $\mathrm{L}^{-1} \gg 1 \mathrm{meq} \mathrm{L}^{-1}$ 
explainability of each parameter, in relation to this factor. The normalized weights, $\mathrm{w}_{\mathrm{i}}$, computed through Equation 2, are listed in Table 4.

Table 4 - Weights for the WQI parameters

\begin{tabular}{ll}
\hline \multicolumn{1}{c}{ Parameters } & Wi \\
\hline Electrical Condutivity $(\mathrm{EC})$ & 0.211 \\
Sodium $\left(\mathrm{Na}^{+}\right)$ & 0.204 \\
Bicarbonate $\left(\mathrm{HCO}_{3}^{-}\right)$ & 0.202 \\
Chloride $\left(\mathrm{Cl}^{-}\right)$ & 0.194 \\
Sodium Adsorption Ration $\left(\mathrm{SAR}^{\circ}\right)$ & 0.189 \\
\hline Total & 1.000 \\
\hline
\end{tabular}

Division in classes based on the proposed water quality index was based on existent water quality indexes, and classes were defined considering the risk of salinity problems, soil water infiltration reduction, as well as toxicity to plants as observed in the classifications presented by Bernardo (1995) and Holanda and Amorim (1997). Restrictions to water use classes were characterized as shown in Table 5.

Based on the results observed in Table 5, there is a limited use of water for irrigation purposes on the western side of the basin of the Acaraú River, where the dams of Araras (A3) and Ayres de Souza (A4), Jaibaras River (R5) as well as Acaraú Mirim dam (A8) are located. Those reservoirs and the river showed an average WQI of $34 ; 17$; 24; and 37, respectively (FIG. 2A). Most water samples

Table 5 - Water Quality Index Characteristics

\begin{tabular}{|c|c|c|c|}
\hline \multirow{2}{*}{ WQI } & \multirow{2}{*}{ Water use restrictions } & \multicolumn{2}{|c|}{ Recomendation } \\
\hline & & Soil & Plant \\
\hline $85 \leq 100$ & No restriction (NR) & $\begin{array}{l}\text { May be used for the majority of } \\
\text { soils with low probability of causing } \\
\text { salinity and sodicity problems, being } \\
\text { recommended leaching within irrigation } \\
\text { practices, except for in soils with } \\
\text { extremely low permeability. }\end{array}$ & No toxicity risk for most plants \\
\hline $70 \leq 85$ & Low restriction (LR) & $\begin{array}{c}\text { Recommended for use in irrigated } \\
\text { soils with light texture or moderate } \\
\text { permeability, being recommended salt } \\
\text { leaching. Soil sodicity in heavy texture } \\
\text { soils may occur, being recommended } \\
\text { to avoid its use in soils with high clay } \\
\text { levels } 2: 1 .\end{array}$ & Avoid salt sensitive plants \\
\hline $55 \leq 70$ & Moderate restriction (MR) & $\begin{array}{l}\text { May be used in soils with moderate } \\
\text { to high permeability values, being } \\
\text { suggested moderate leaching of salts. }\end{array}$ & $\begin{array}{c}\text { Plants with moderate tolerance } \\
\text { to salts may be grown }\end{array}$ \\
\hline $40 \leq 55$ & High restriction (HR) & $\begin{array}{l}\text { May be used in soils with high } \\
\text { permeability without compact layers. } \\
\text { High frequency irrigation schedule } \\
\text { should be adopted for water with EC } \\
\text { above } 2.000 \mathrm{dS} \mathrm{m}-1 \text { and SAR above } 7.0 \text {. }\end{array}$ & $\begin{array}{l}\text { Should be used for irrigation } \\
\text { of plants with moderate to high } \\
\text { tolerance to salts with special } \\
\text { salinity control practices, } \\
\text { except water with low } \mathrm{Na}, \mathrm{Cl} \\
\text { and } \mathrm{HCO}_{3} \text { values }\end{array}$ \\
\hline $0 \leq 40$ & Severe restriction (SR) & $\begin{array}{l}\text { Should be avoided its use for irrigation } \\
\text { under normal conditions. In special } \\
\text { cases, may be used occasionally. Water } \\
\text { with low salt levels and high SAR } \\
\text { require gypsum application. In high } \\
\text { saline content water soils must have high } \\
\text { permeability, and excess water should be } \\
\text { applied to avoid salt accumulation. }\end{array}$ & $\begin{array}{l}\text { Only plants with high salt } \\
\text { tolerance, except for waters } \\
\text { with extremely low values of } \\
\quad \mathrm{Na}, \mathrm{Cl} \text { and } \mathrm{HCO}_{3} \text {. }\end{array}$ \\
\hline
\end{tabular}




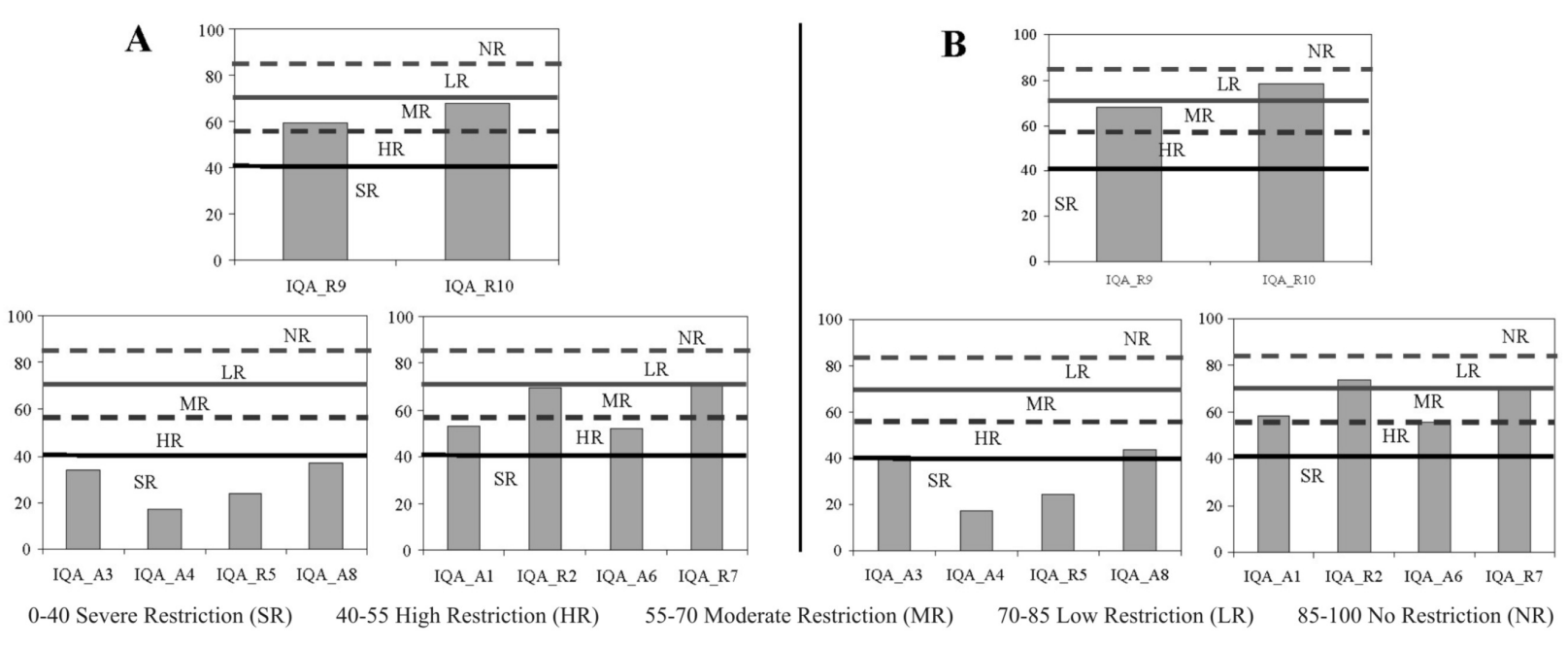

Figure 2 - Average WQI values for the points R9 and R10 of the Acaraú river, western part of the basin (A3, A4, R5 and A8), and eastern part (A1, R2, A6 and R7), considering the entire studied period (Graph A) and only the dry period (Graph B)

are in the severe restriction class. Especially during the dry period, when irrigation is needed, these sampling points showed high to severe restrictions. Studies developed by Rhoades et al. (1992), De Nys et al. (2002) and Pearson (2003) considering the concentration of salts in irrigation water, they show the importance of the balance of salts and excessive leaching the stability of soil aggregates that might cause problems of reduced infiltration, reduced hydraulic conductivity and/or presence of surface crust. These results are associated to the low levels of EC and SAR measured over the studied period.

Studies developed by Andrade et al. (2006) define soils with low to moderate permeability where sampling sites A3; A4; A8 and R5 are located, with limiting use due to low infiltration rates, with high risk to future infiltration problems in irrigation.

That behavior was described by Chaves (2006) in the Araras Northern Irrigation District in the upper basin, western part of the Basin of Acaraú River, where infiltration reduction with irrigation water accumulation on the soil surface was observed. A loss in soil permeability reduced soil drainage, inducing salinization problems with waters that, according to the USDA classification, did not pose a risk.

Edson Queiroz (A1) and Forquilha (A6) dams showed temporal variation of the WQI about an average of 53 and 52 (FIG. 2A), respectively. These values are in the class with high restriction, although very close to the upper limit. In the dry period (FIG. 2B), average WQI in the dams was 59 and 55, respectively, with moderate restriction of use.
Soils in the region of these reservoirs show low to moderate natural drainage in the presence of with clay 2:1 (ANDRADE et al., 2006). These soils, with sodium in B horizon should be used with care when irrigated, especially in arid regions with high evapotranspiration rates.

Groaíras river (R2) and Forquilha irrigation perimeter drain (R7), were the sites with the highest salinity of all sampling sites, with an average WQI of 70 and 71 (FIG. 2A), respectively. These values are within the low restriction class for irrigation. This classification was repeated in the dry period (FIG. 2B). However, then, restriction is related to infiltration reduction (EC x SAR). Total salt concentration and specific ion concentration $\left(\mathrm{Na}^{+}, \mathrm{Cl}^{-}\right.$, and $\left.\mathrm{HCO}_{3}^{-}\right)$should be considered to avoid damage to plants.

Water in Santa Rosa dam (R9) and Acaraú river (R10) had an average WQI of 60 and 68 (FIG. 2A), respectively, in the class with moderate restrictions. It should be emphasized that R9 sampling point showed an average WQI of 68 in the dry period and a value of 78 in the year 2004. This sources of water supplies the irrigation scheme Distrito de Irrigação Baixo Acaraú - DIBAU which irrigates a total of 8,438 ha, and the water may be considered adequate for use.

Water quality spatial variability in the basin was higher during the intense rainfall period. In April/2003 and January/2004 coefficients of variation (CV) of $72.8 \%$ and $79.3 \%$ were observed, with WQI average values of 37 and 30, respectively. This strong variation in the rainy season was observed also by Frota Júnior (2006) along 
Curu River. According to the referred author, the strong variation of data in the period expresses the dynamics of water quality influenced by human interventions and seasonality of flow at each point.

\section{Conclusions}

1.Factor/Principal Component Analysis permitted the description of parameters involved in the processes that define water quality in the Basin of Acaraú River through a three component model, the components of which explain $72.3 \%$ of total data variance, previously diluted in thirteen dimensions;

2. Water samples taken from the western part of the Basin of Acaraú River had WQI lower than 40, falling within the class of use with severe restrictions for irrigation, posing potential problems of reduction of infiltration due to water sodicity, and low levels of salinity observed in these reservoirs throughout the year;

3. Water sampled at the Edson Queiroz and Forquilha dams, located on eastern part of the Basin were classified in class with high water use restrictions for irrigation in both the dry and rainy period;

4. Average value of WQI in Santa Rosa dam, water which supplies the irrigation scheme Distrito de Irrigação Baixo Acaraú, was 60, of a moderate restriction in use for irrigation. However, in the dry period the WQI values increased to 68 , towards low restriction condition.

\section{Acknowledgements}

The authors express their gratitude for the financial support of the Conselho Nacional de Desenvolvimento Científico e Tecnológico (CNPq) and the Coordenação de Aperfeiçoamento de Pessoal de Nível Superior (CAPES).

\section{References}

ALMEIDA, M. A. B.; SCHWARZBOLD, A. Avaliação sazonal das águas do Arroio da Cria Montenegro, RS com aplicação de um índice de qualidade de água (IQA). Revista Brasileira de Recursos Hídricos, v. 08, n. 01, p. 81-97, 2003.

ANDRADE, E. M. et al. Índice de qualidade de água, uma proposta para o vale do rio Trussu, Ceará. Revista Ciência Agronômica, v. 36, n. 02, p. 135-142, 2005.

ANDRADE, E. M. et al. Mapa de vulnerabilidade da bacia do Acaraú, Ceará, à qualidade das águas de irrigação, pelo emprego do GIS. Revista Ciência Agronômica, v. 37 n. 03, p. 280-287, 2006.
AYERS, R. S.; WeStCOT, D. W. A Qualidade da Água na Agricultura. 2. ed. Campina Grande: UFPB, 1999. 218 p. (Estudos FAO: Irrigação e Drenagem, 29)

BERNARDO, S. Manual de Irrigação. 4. ed. Viçosa: UFV, 1995. $488 \mathrm{p}$.

BOLLMANN, H. A.; MARQUES, D. M. Bases para a estruturação de indicadores de qualidade de águas. Revista Brasileira de Recursos Hídricos, v. 05, n. 01, p. 37-60, 2000.

BRODNJAK-VONCINA, D.; et al. Chemometrics characterization of the quality of river water. Analytica Chimica Acta, v. 462, n. 01, p. 87-100, 2002.

CHAVES, L. C. G. Salinidade e impacto da irrigação no Distrito de Irrigação do Perímetro Irrigado Araras Norte, Dipan, Ceará. 2006, 79 f. Dissertação (Mestrado em Irrigação e Drenagem) - Universidade Federal do Ceará, Fortaleza.

DE NYS, E. et al. Evaluation of the salinization pattern of irrigated fields in Maniçoba irrigation scheme (Brazil). Disponível em: $<$ http://www.pcsi.ird.fr/sempcsi2/communications/DeNys.pdf $>$. Acesso em: 9 set. 2005.

DILLON, W. R.; GOLDSTEIN, M. Multivariate analysis methods and applications. New York: John Wiley e Sons, 1984. $587 \mathrm{p}$.

ELMI, A. A. et al. Water and fertilizer nitrogen management to minimize nitrate pollution from a cropped soil in southwestern Quebec, Canada. Water Air Soil Pollution, v. 151, n. 1/4, p. 117-134, 2004.

FROTA JÚNIOR, J. I. Variabilidade especial e temporal da qualidade das águas no trecho perenizado da bacia hidrográfica do Curu, Ceará. 2006. 103 f. Dissertação (Mestrado em Irrigação e Drenagem) - Universidade Federal do Ceará.

FUNDAÇÃO CEARENCE DE METEREOLOGIA E RECURSOS HÍDRICOS (FUNCEME). Monitoramento hidroambiental-chuvas. 2002. Disponível em: <http://www. funceme.br/DEPAM/index.htm>. Acesso em: 12 set. 2008.

GHEYI, H. R. Problemas de salinidade na agricultura irrigada. In: OLIVEIRA, T. S.; ASSIS JÚNIOR, R. N.; ROMERO, R. E.; SILVA, J. R. C. Agricultura, Sustentabilidade e o SemiÁrido. Fortaleza: UFC; Viçosa: Sociedade Brasileira de Ciências do Solo, 2000. p. 329-356.

HAASE, J.; KRIEGER, J. A.; POSSOLI, S. Estudo da viabilidade do uso da técnica factorial como um instrumento na interpretação de qualidade das águas da bacia hidrográfica do Guaíbas, RS, Brasil. Ciência e Cultura, v. 41, n. 06, p. 576-582, 1989.

HAIR JUNIOR, J. F. et al. Análise multivariada de dados. 5. ed. Porto Alegre: Bookman, 2005. 593 p.

HELENA, B. et al. Temporal evolution of groundwater composition in an alluvial aquifer (Pisuerga river, Spain) by principal component analysis. Water Research, v. 34 n. 03, p. 807-816, 2000.

HOLANDA, J. S.; AMORIM, J. A. Manejo e controle da salinidade da água na agricultura irrigada. In: CONGRESSO BRASILEIRO DE ENGENHARIA AGRÍCOLA, 26., 1997. 
Campina Grande. Anais... Campina Grande: SBEA, 1997. p. 137-169.

INSTITUTOBRASILEIRODEGEOGRAFIAEESTATÍSTICA (IBGE). Indicadores de desenvolvimento sustentável: Brasil 2002. Rio de Janeiro: IBGE, 2002. 195 p. Disponível em: <http:// www.scribd.com/doc/6944615/Indicadores-de-to-SustentavelBrasil-2002-IBGE>. Acesso em: 10 jan. 2009.

INSTITUTO DE PLANEJAMENTO DO CEARÁ (IPLANCE). Atlas do Ceará. Fortaleza: IPLANCE, 1997. 1 CD-ROM.

MENDIGUCHIA, C. et al. Using chemometric tools to assess anthropogenic effects in river water. A case study: Guadalquivir river (Spain). Analytica Chímica Acta, v. 515, n. 01, p. 143-149, 2004.

NORUSIS, M. J. SPSS Base System User's Guide. Chicago: SPSS Inc., $1990.520 \mathrm{p}$.

OTT, W. R. Environmental Indices: theory and practice. Michigan: Ann Arbor Science, Ann Arbor, 1978. 371 p.

PARINET, B.; LHOTE, A.; LEGUBE, B. Principal component analysis: an appropriate tool for water quality evaluation and management - application to a tropical lake system. Ecological Modelling, v. 178, n. 03/04, p. 295-311, 2004.

PEARSON, K. E. The basics of salinity and sodicity effects on soil physical properties. Disponível em: $<\mathrm{http}$ ://waterquality. montana.edu/docs/methane/basics_highlight.shtml $>$. Acesso em: 14 oct. 2006.

PESCE, S. F.; WUNDERLIN, D. A. Use of water quality indices to verify the impact of Córdoba city (Argentina) on Suquia river. Water Research, v. 34 n. 11, p. 2915-2926, 2000.
PRADO, P. I. et al. Ordenação multivariada na ecologia e seu uso em ciências ambientais. Ambiente e Sociedade, n. 10, p. 69-83, 2002.

RHOADES, J. D.; KANDIAH, A.; MASHAL, A. M. The use of saline water for crop production. Rome: FAO, $1992.133 \mathrm{p}$. (FAO. Irrigation and Drenage Paper, 48).

RICHARDS, L. A. Diagnosis and improvement of saline and alkali soil. Washington DC, US Department of Agriculture, 1954. 160 p. (USDA Agriculture Handbook, 60).

SIMEONOV, V. et al. Assessment of the surface water quality in Northern Greece. Water Research, v. 37, n. 17, p. 4119-4124, 2003.

SUAREZ, D. L. Relation between $\mathrm{pHc}$ and sodium adsorption ratio (SAR) and an alternative method of estimating SAR of soil or drainage waters. Soil Science. Society of America Journal, v. 45, p. $469-75,1981$.

TOLEDO, L. G., NICOLELLA, G. Índice de qualidade de água em microbacia sob o uso agrícola e urbano. Scientia Agrícola, v. 59 n. 01, p. 181-186, 2002.

VEGA, M.; BARRADO, E.; DEBAN, L. Assessment of seasonal and polluting effects on the quality of river water exploratory data analysis. Water Research, v. 32, n. 12, p. 3581-3592, 1998.

WUNDERLIN, D. A. et al. Pattern recognition techniques for the evaluation of spatial and temporal variations in water quality. A case study: Suquía River Basin (Córdoba-Argentina). Water Research, v. 35, n. 12, p. 2881-2894, 2001. 